\title{
Effects of Reclaimed Municipal Waste Water on Horticultural Characteristics, Fruit Quality, and Soil and Leaf Mineral Concentration of Citrus
}

\author{
Kelly T. Morgan ${ }^{1}$ \\ Soil and Water Science Department, University of Florida, Southwest \\ Florida REC, 2686 SR 29 N, Immokalee, FL 34142

\section{T. Adair Wheaton, Larry R. Parsons, and William S. Castle Horticultural Sciences Department, University of Florida, Citrus REC, 700 Experiment Station Road, Lake Alfred, FL 33850}

Additional index words. oranges, Citrus sinensis L., Entisols, reclaimed water, Florida, nutrition, irrigation

\begin{abstract}
Water Conserv II is a municipal reclaimed water project operated by the city of Orlando and Orange county, FL. The Water Conserv II project has been supplying high-quality reclaimed water for irrigation of citrus orchards, nurseries, greenhouse operations, golf courses, and residential landscapes in Orange and Lake counties since 1986. Selected commercial citrus orchards in the Water Conserv II service area receiving either groundwater or reclaimed water have been monitored quarterly since the project began. This yearly monitoring was undertaken to determine any adverse long-term effects on citrus tree growth or production associated with irrigation using this reclaimed water. Citrus blocks were rated for horticultural condition quarterly, fruit quality was determined before harvest, and soil and leaf samples were analyzed yearly from 1994 to 2004. Citrus growers irrigating with reclaimed water were encouraged to use higherthan-recommended amounts of water as a means of disposal of this reclaimed water resulting in increased weed growth and dilution of juice solids per box of fruit. Leaf boron and magnesium were significantly higher after irrigation with reclaimed water. Calcium and boron from the reclaimed water have eliminated the need in orchards receiving reclaimed water for liming of the soil and applying annual foliar sprays containing boron.
\end{abstract}

Florida has experienced rapid growth in population during the last 50 years with a 5.5fold population increase from 1950 to 2000 (Perry and Mackum, 2001; Smith, 2005; U.S. Census Bureau, 1997). Groundwater withdrawal for domestic and irrigation use has increased by 15.5 and 20.7 times, respectively, during the same period (Marella and Berndt, 2005). Likewise, the amount of wastewater generated by cities in Florida has increased more than fivefold since 1950. Environmental concerns about degradation of surface waters by treated effluent water have caused many communities to consider advanced secondary-treated wastewater (reclaimed water) reuse. Currently, there are 440 reclaimed water reuse systems in Florida irrigating 92,345 ha with 2385 million liters of reclaimed water per day

\footnotetext{
Received for publication 27 June 2007. Accepted for publication 19 Oct. 2007.

We gratefully acknowledge the financial support of The City of Orlando and Orange County without whom this research would not have been possible. ${ }^{1}$ To whom reprint requests should be addressed; e-mailktm@ifas.ufl.edu
}

(Florida Department of Environmental Protection, 2005). The majority of these systems irrigate golf courses, public right-of-ways, and home landscapes. However, 6144 ha of production agriculture is currently irrigated with reclaimed water with citrus (Citrus spp. L.) orchards accounting for all but 364 ha.

Florida citrus production benefits from irrigation because the average annual rainfall of more than $1200 \mathrm{~mm}$ is unevenly distributed throughout the year with $\approx 75 \%$ of annual rainfall occurring from June to September (Koo, 1963). Furthermore, Florida citrus trees are grown on sandy soils with very low water-holding capacity, particularly orchards in the central "ridge" portion of the state. Typical available water content values for central Florida ridge citrus soils range from 0.05 to $0.08 \mathrm{~cm}^{3} \cdot \mathrm{cm}^{-3}$ (Obreza and Collins, 2003). Increased water use by the growing population and localized water shortages during low rainfall years have resulted in the development of water use restrictions and decreases in permitted water use for agriculture. Increased use of reclaimed water for agricultural irrigation would not only reduce the wastewater dis- posal problem for urban areas, but could also reduce the amount of water withdrawn from surficial and Floridan aquifers for irrigation.

Before 1986, the city of Orlando and Orange county were discharging treated effluent into Shingle Creek that leads into Lake Tohopekaliga in central Florida. As a result of concerns that nutrient loading from this effluent would reduce lake water quality, Orlando and Orange county, along with the U.S. Environmental Protection Agency, developed a plan to use the wastewater normally disposed of in Shingle Creek for agricultural irrigation instead. Initial funding of $\$ 180,000,000$ established the project, which is called Water Conserv II (Parsons et al., 2001a). The project currently delivers $\approx 133,000 \mathrm{~m}^{3}$ of reclaimed water per day (cmd) $(275,000 \mathrm{cmd}$ maximum flow) to $\approx 1750$ ha of citrus (Phil Cross, pers. comm., 2006). Other users of reclaimed water from the Water Conserv II project are eight foliage greenhouse operations, four tree farms, two ferneries, and three golf courses. The reclaimed water is distributed though $80 \mathrm{~km}$ of pipelines maintained by the project. Excess reclaimed water is disposed of in 71 ha of rapid infiltration basins that recharge surficial and Floridan aquifers. Water Conserv II is the largest reclaimed water agricultural irrigation project of its type in the world and was the first project in Florida to be permitted to irrigate crops for human consumption with reclaimed water (McMahon et al., 1989).

The reclaimed water distributed by the Water Conserv II project and used for irrigation of orchards in this study was treated with advanced secondary treatment with high-level disinfection, coagulation, filtration, and chlorination (Parsons et al., 2001b). Water quality standards were negotiated among Water Conserv II, Univ. of Florida researchers, and local growers.

To receive reclaimed water for irrigation at no cost, citrus growers were required to sign a contract with the city of Orlando and Orange county to accept $1270 \mathrm{~mm}$ of water per year for a period of at least 20 years. Initially, there was grower resistance because of concerns that use of the reclaimed water might damage citrus trees or make the fruit unmarketable. As part of the contract, the growers requested that the Univ. of Florida study the long-term effects of reclaimed water on citrus tree health and fruit quality. Dr. R.C.J. Koo of the Univ. of Florida (IFAS) Citrus Research and Education Center initiated a study to determine tree appearance (i.e., foliage density and color), weed growth, leaf nutrient status, and soil nutrient retention in citrus orchards irrigated with either groundwater or reclaimed water in 1987. No adverse affects of reclaimed water use on tree health and productivity were noted in the initial phase of the orchard survey; however, continued monitoring was suggested to determine long-term effects (i.e., metal accumulation in soil, leaves, or fruit). Orchards are not now required to accept the full $1270 \mathrm{~mm}$ of water per year under the contract because 
rapid infiltration basins (RIBs) were installed in the early 1990s. As a result of the highly porous nature of the soils, the RIBs function as alternate disposal sites (particularly during the normally wet summer rainy season) where the reclaimed water is applied at high rates and allowed to percolate to the groundwater. Still questions persisted regarding the effect of long-term use of wastewater on tree productivity.

This orchard monitoring project continued through the 1990s and was ended in 2004. This article reports data collected since the preliminary reporting of results in 1993 (Zekri and Koo, 1993) to the conclusion of the study in 2004. The monitoring of citrus orchards was continued to determine if adverse effects on citrus tree health and production were associated with irrigation using reclaimed water. Therefore, the objective of this project was to determine whether long-term irrigation with treated municipal wastewater 1) reduces tree health (i.e., canopy appearance and leaf nutrient content), 2) decreases visual fruit loads, 3) impacts internal fruit quality (i.e., Brix, titratable acid, Brix:acid ratio), or 4) increases in soil contaminant concentrations.

\section{Materials and Methods}

The Water Conserv II project distributes reclaimed water to users in western Orange and eastern Lake counties in central Florida (lat. $28^{\circ} 28^{\prime} 20^{\prime \prime} \mathrm{N}$, long. $81^{\circ} 38^{\prime} 50^{\prime \prime} \mathrm{W}$, elevation $64 \mathrm{~m}$ ). The reclaimed water meets drinking water standards for nitrate-N (Table
1 ), is low in heavy metal concentrations (i.e., cadmium, chromium, lead, and mercury), and has no odor or color. Grower benefits include a free source of high-quality irrigation water maintained below established maximum mineral and metal concentration levels (Table 1) delivered at a minimum pressure of $276 \mathrm{kPa}$. The predominant soil order in this area is Entisol, with Candler fine sand (hyperthermic, uncoated, Typic Quartzipsamment) being the dominant soil series (Obreza and Collins, 2003). The Candler series consists of excessively drained, very rapidly permeable soils formed from marine deposits. These soils are located in upland areas and typically have slopes of $0 \%$ to $12 \%$. The A and E horizons consist of singlegrained fine sand, have a loose texture, and are strongly acidic ( $\mathrm{pH}=4.0$ to 5.5$)$. A Bt horizon is located at a soil depth of $2 \mathrm{~m}$ and includes loamy lamellae of 0.1 to $3.5 \mathrm{~cm}$ thick and 5 to $15 \mathrm{~cm}$ long.

Before 1994, unequal numbers of sampled commercial orchards were irrigated with the two water sources but did not have the same citrus scion cultivars. In 1994, 10 orchards irrigated with one of the two water sources were selected for a total of 20 orchards. These 20 orchards were paired so that trees of the same scion and relative age were irrigated with either water sources. The scions used were 'Hamlin' and 'Valencia' oranges ( $C$. sinensis L.), 'Sunburst' tangerine (C. reticulata Blanco), and 'Orlando' tangelo (C. reticulata Blanco $\times$ C. paradisi Macfadyn); however, the root stocks were not always consistent among the two water sources.

Table 1. Maximum allowable contaminate limit (MACL) for Florida drinking water and Conserv II reclaimed water and typical Water Conserv II reclaimed water concentrations. ${ }^{z}$

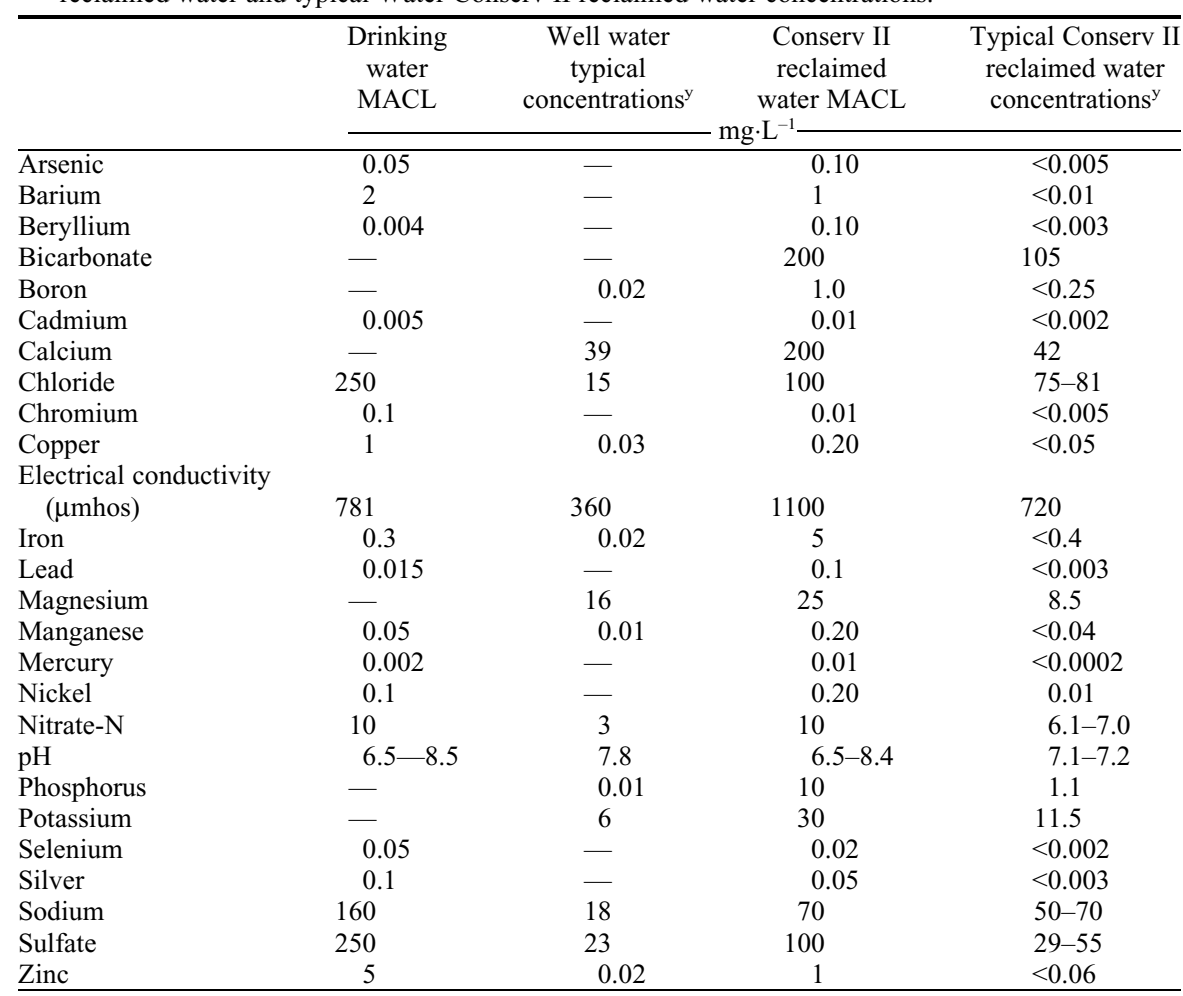

${ }^{\mathrm{z}} \mathrm{All}$ values are in $\mathrm{mg} \cdot \mathrm{L}^{-1}$ except for $\mathrm{pH}$ and electrical conductivity.

${ }^{\mathrm{y}}$ As reported in Parsons et al., 2001b.

Random trees over a 4-ha plot in each orchard were evaluated quarterly for canopy appearance, leaf color, fruit crop, and weed cover. Each orchard received a separate visual rating for each category on a 1 to 5 scale. A rating of 1 indicates a less dense canopy compared with visual inspection of orchards in the area at the same time period, leaf color would be chlorotic or have visual deficiency symptoms, the fruit crop would be low enough to be unharvestable, and the weed population would be very low indicating insufficient nutrition, soil water content, or excess herbicide application. Ratings of 5 would indicate a thick dense canopy with excessive vegetative growth, dark green leaves with nitrogen concentrations above that considered optimum, a fruit crop considered to be well above the average for trees of comparable age and size in the area, and a dense weed population in the herbicide zone well in excess of standard grower practices. Fruit samples (20 fruit) were taken from five trees in each orchard just before harvest and analyzed for percent juice content, Brix, acid, and weight. Degrees Brix and total titratable acidity were determined according to methods approved for Florida citrus quality tests (Wardowski et al., 1995).

Samples of spring growth leaves (20 leaves from five trees) and soil (two cores from each of five trees) were taken from each orchard in August or September of each year from 1994 to 2004. Leaf samples were analyzed for $\mathrm{N}, \mathrm{P}, \mathrm{K}, \mathrm{Ca}, \mathrm{Mg}, \mathrm{Na}, \mathrm{Zn}, \mathrm{Mn}, \mathrm{Fe}$, and B. Soil samples were taken at the same time to a depth of $60 \mathrm{~cm}$ and were analyzed for $\mathrm{P}, \mathrm{K}, \mathrm{Ca}, \mathrm{Mg}, \mathrm{Zn}, \mathrm{Mn}, \mathrm{Al}, \mathrm{Cu}, \mathrm{Fe}, \mathrm{Na}$, and $\mathrm{Cl}$. Leaf samples were dried at $70{ }^{\circ} \mathrm{C}$ to a constant weight and ground using a Cyclotec mill (Tecator Manufacturing, Tecator, Sweden). Ground tissue was analyzed for $\mathrm{N}$ by Kjeldahl methods (U.S. EPA, method 351.2) using steam distillation (Buchi Analytical, New Castle, DE). Other leaf elemental concentrations were determined using nitric acid/hydrogen peroxide digestion and determination with inductively coupled plasma (ICP) spectroscopy (Hanlon and DeVore, 1989). Soil samples were extracted using Mehlich 1 (5 g of dry soil in $20 \mathrm{~mL}$ of extractant) and analyzed by ICP spectroscopy.

Because the orchards were paired by age and scion, horticultural ratings, fruit quality, and leaf and soil sample analysis data were analyzed by irrigation water source using analysis of variance using SAS Proc GLM (SAS, 1989). However, because only two scions (Hamlin and Valencia) of similar ages were in only two orchards each, no comparison of the effect of irrigation water source by scion was possible.

\section{Results and Discussion}

Citrus orchards in this project were irrigated with either groundwater or reclaimed water. Orchards irrigated with groundwater were managed using recommended practices receiving 30 to $60 \mathrm{~cm}$ of irrigation per year. However, orchards irrigated with reclaimed 
water had higher soil water content (Zekri and Koo, 1993), presumably because of more frequent irrigation. Orchards irrigated with reclaimed water had soil moisture content of $0.06 \mathrm{~cm}^{3} \cdot \mathrm{cm}^{-3}$ compared with $0.05 \mathrm{~cm}^{3} \cdot \mathrm{cm}^{-3}$ for orchards irrigated with groundwater. Field capacity was estimated to be 0.65 $\mathrm{cm}^{3} \cdot \mathrm{cm}^{-3}$ for these soils, indicating that orchards irrigated with reclaimed water were near or above field capacity a higher proportion of the time compared with orchards irrigated with groundwater. The quality of the reclaimed water used for irrigation was monitored monthly, and a report of average water constituent concentrations was provided to the growers (Table 1). Reclaimed water provided to citrus orchards by the Water Conserv II project is of very good quality and consistently within drinking water standards for all constituents, including heavy metals. Fertilizer macroelements (N, P, K, and $\mathrm{Mg}$ ) are two to more times greater in the reclaimed water than well water, particularly for phosphorus, which is 10 times greater. The level of constituent concentrations in the reclaimed water is not considered to be toxic (Burton and Hook, 1979; Feigin et al., 1984). However, if soil or tissue accumulation were to occur, concentrations of heavy metals (i.e., cadmium, lead, and zinc) may approach toxic levels (Campbell et al., 1983; Feigin et al., 1984; Neilsen et al., 1991).

Horticultural ratings. Before 1994, Zekri and Koo (1993) reported that soil to a depth of $0.5 \mathrm{~m}$ beneath trees irrigated with reclaimed water was usually $14.7 \mathrm{~mm}$ higher in water content and the trees had 6\% higher canopy, leaf color, and fruit crop ratings than trees irrigated with groundwater. The higher ratings were attributed to consistently higher soil water content in the orchards irrigated with reclaimed water. For the period 1994 to 2004, mean quarterly canopy appearance, leaf color, and fruit crop were significantly higher in orchards irrigated with reclaimed water compared with orchards irrigated with groundwater (Table 2). Weed growth in orchards irrigated with reclaimed water was consistently higher, but not significantly different, than orchards irrigated with well water. The difference in mean rating for the four categories was $12.3 \%$, possibly indicating greater water use in reclaimed water blocks compared with orchards irrigated with well water.

Horticultural ratings for canopy appearance, leaf color, and fruit crop had significant year*water source interactions (Table 2). Mean canopy, leaf color, and fruit crop ratings for trees irrigated with groundwater were significantly greater than ratings from 2000 to 2004 compared with trees irrigated with the same water source from 1996 to 1999, whereas canopy, leaf color, and fruit crop ratings for the orchards irrigated with reclaimed water did not have a similar pattern. Reduced canopy appearance, leaf color, and fruit set in orchards irrigated with groundwater can be attributed to reduced rainfall from 1994 to 1999 (390 mm, 1998) compared with average rainfall from 2000 to $2004(1191 \mathrm{~mm})$. Significantly lower tree appearance in a drought year agrees with conclusions of Zekri and Koo (1993) that commercial citrus orchards irrigated with reclaimed water were commonly irrigated more frequently or with a greater volume than those irrigated with groundwater.

Weed growth as measured by weed cover ratings was higher in reclaimed water-irrigated orchards for most years compared with those irrigated with groundwater (Table 2). Higher weed growth ratings have been correlated with high irrigation rates of reclaimed water (Parsons and Wheaton, 1992; Zekri and Koo, 1993). Like with tree appearance and fruit crop, weed cover ratings only were significantly lower for orchards irrigated with groundwater in 1998 compared with other years, presumably as a result of lower rainfall. Growers have adjusted their herbicide practices to reduce the negative impact of increased weed growth resulting from higher irrigation use with reclaimed water by reducing reclaimed water use or increasing herbicide applications (John Jackson, personal communication, 2006)

Fruit quality. In 5 of 11 years (1994, 1995, 1998, 2000, and 2001), mean fruit juice content or the percent of fruit weight in juice was significantly higher among trees in orchards irrigated with reclaimed water rather than groundwater (Table 3). These years with significant juice content differences among irrigation water sources lead to a significant year* water source interaction for juice content. Juice soluble solids or Brix was not significantly different among water sources. However, Brix was significantly different among water sources in 1994, 1997, and 1998 contributing to a significant year*water source interaction. Two of these years were considered dry years with belownormal rainfall. Fruit weight was significantly higher for orchards irrigated with reclaimed water compared with fruit from orchards irrigated with groundwater; however, no year*water source interaction was noted. Therefore, higher fruit crop ratings, fruit weights, and similar solids per fruit (during normal rainfall years) in orchards irrigated with reclaimed water would suggest similar or greater yields in terms of soluble solids per hectare compared with orchards irrigated with groundwater. The previous study by Koo and Zekri (1989) found that reduced soluble solids and acid concentration in the juice was correlated with higher soil water content in the orchards receiving reclaimed water. Likewise, significant differences in fruit Brix and acid were seen in this study from 1994 to 1998 , but not after 1998. This change in fruit Brix and acid may indicate a change in irrigation practices with orchards being irrigated with similar amounts some time after 1998. This shift in irrigation practice would correspond with construction of RIBs and reduced requirement for the use of reclaimed water. Because fruit yield was greater from orchards irrigated with reclaimed water, total soluble solids

Table 2. Mean horticultural rating of citrus orchards taken in January, April, July, and October of each year from orchards irrigated with reclaimed or groundwater between 1994 and 2004.

\begin{tabular}{|c|c|c|c|c|c|c|c|c|c|c|c|c|}
\hline \multirow[b]{3}{*}{$\mathrm{Yr}$} & \multicolumn{3}{|c|}{ Canopy } & \multicolumn{3}{|c|}{ Leaf color } & \multicolumn{3}{|c|}{ Fruit crop } & \multicolumn{3}{|c|}{ Weed cover } \\
\hline & $\begin{array}{c}\text { Reclaimed } \\
\text { water }\end{array}$ & $\begin{array}{c}\text { Ground } \\
\text { water }\end{array}$ & Mean & $\begin{array}{c}\text { Reclaimed } \\
\text { water }\end{array}$ & $\begin{array}{l}\text { Ground } \\
\text { water }\end{array}$ & Mean & $\begin{array}{l}\text { Reclaimed } \\
\text { water }\end{array}$ & $\begin{array}{c}\text { Ground } \\
\text { water }\end{array}$ & Mean & $\begin{array}{c}\text { Reclaimed } \\
\text { water }\end{array}$ & $\begin{array}{c}\text { Ground } \\
\text { water }\end{array}$ & Mean \\
\hline & & & & & 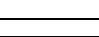 & $-1-5$ & ting & & & & & \\
\hline 1994 & 3.7 & 3.2 & 3.5 & 3.3 & 3.4 & 3.3 & 3.4 & 3.4 & 3.4 & 3.6 & 3.2 & 3.4 \\
\hline 1995 & 3.7 & 3.1 & 3.4 & 3.5 & 3.1 & 3.3 & 3.9 & 3.7 & 3.8 & 4.0 & 3.7 & 3.8 \\
\hline 1996 & 3.7 & 3.2 & 3.4 & 3.4 & 3.2 & 3.3 & 3.8 & 3.3 & 3.6 & 3.4 & 3.6 & 3.0 \\
\hline 1997 & 3.8 & 3.1 & 3.4 & 3.4 & 2.8 & 3.1 & 3.7 & 3.4 & 3.5 & 3.8 & 3.5 & 3.6 \\
\hline 1998 & 3.9 & 3.0 & 3.4 & 3.8 & 3.1 & 3.4 & 3.9 & 3.3 & 3.5 & 3.2 & 2.7 & 3.0 \\
\hline 1999 & 3.8 & 2.9 & 3.4 & 3.7 & 3.5 & 3.6 & 3.4 & 3.4 & 3.4 & 3.5 & 3.6 & 3.5 \\
\hline 2000 & 4.2 & 3.7 & 4.0 & 4.1 & 3.7 & 3.9 & 2.9 & 3.2 & 3.0 & 3.4 & 3.1 & 3.2 \\
\hline 2001 & 4.0 & 3.4 & 3.7 & 3.9 & 3.5 & 3.7 & 3.6 & 3.3 & 3.4 & 3.2 & 3.1 & 3.1 \\
\hline 2002 & 4.0 & 3.6 & 3.8 & 3.8 & 3.2 & 3.5 & 2.9 & 3.4 & 3.1 & 3.1 & 3.2 & 3.1 \\
\hline 2003 & 4.2 & 3.7 & 3.9 & 4.1 & 3.7 & 3.9 & 3.8 & 3.5 & 3.6 & 3.2 & 3.0 & 3.1 \\
\hline 2004 & 4.1 & 3.4 & 3.7 & 3.8 & 3.5 & 3.6 & 3.6 & 3.4 & 3.5 & 3.1 & 3.1 & 3.3 \\
\hline Mean & 3.9 & 3.3 & 3.6 & 3.7 & 3.3 & 3.5 & 3.6 & 3.3 & 3.5 & 3.4 & 3.1 & 3.3 \\
\hline \multicolumn{13}{|l|}{ Significance $^{z}$} \\
\hline Year & & & NS & & & NS & & & NS & & & NS \\
\hline Water source & & & $*$ & & & $*$ & & & $*$ & & & NS \\
\hline Year*water source & & & $*$ & & & $*$ & & & $*$ & & & NS \\
\hline
\end{tabular}

${ }^{{ }_{\mathrm{NS}}}$ and $*=$ nonsignificant or significant at $P=0.05$, respectively. 
produced per hectare were higher in the reclaimed water orchards than the groundwater-irrigated orchards.

Soil and leaf nutrient content. Irrigation with reclaimed water has increased soil concentrations of $\mathrm{P}, \mathrm{K}, \mathrm{Mg}, \mathrm{B}, \mathrm{Na}$, and $\mathrm{Cl}$ when reclaimed water was used as an irrigation water source (Burton and Hook, 1979; Campbell et al., 1983; Feigin et al., 1984; Neilsen et al., 1991). Elemental concentrations in soil samples taken in August or September of each year from orchards irrigated with either reclaimed or groundwater varied from year to year but were not significant by years (Table 4). Calcium was the only element significantly different by soil sample depth with higher concentrations found near the surface. This result was expected because calcium was applied as lime applied for $\mathrm{pH}$ adjustments in orchards irrigated with either groundwater or reclaimed water and calcium in the reclaimed water would be incorporated into this layer with little leaching over time. With the exception of increased $\mathrm{P}, \mathrm{Ca}$, and $\mathrm{Al}$, no elements were found to be significantly different when comparing water sources. Soil in orchards irrigated with reclaimed water was significantly higher for $\mathrm{P}, \mathrm{Ca}$, and Al compared with soils in orchards irrigated with groundwater. However, no elements were found to be excessive (Maurer and Davies, 1993; Tucker et al., 1995). Lower extractable soil potassium was found in orchards receiving higher rates of reclaimed water despite the higher potassium concentration of reclaimed water. These data are consistent with findings of Zekri and Koo (1993) who reported $\mathrm{P}, \mathrm{Ca}$, and $\mathrm{Mg}$ were significantly higher and potassium significantly lower in soil samples from orchards irrigated with reclaimed water compared with orchards irrigated with groundwater.

Calcium was the only element with years*water source and depth*water source interactions (Table 4). Soil calcium concentrations were significantly lower (1034.7 $\left.\mathrm{kg} \cdot \mathrm{ha}^{-1}\right)$ in years with normal rainfall $(2000$ to 2004) compared with drier years (1338.5, 1996 to 1999). Differences in soil calcium concentration among the two irrigation water sources followed the same pattern during these years with soil from orchards irrigated with reclaimed water having higher concentrations than soil from orchards with

Table 3. Mean citrus fruit quality parameters from mature fruit samples taken in before harvest of each year from orchards irrigated with reclaimed or groundwater between 1994 and 2004.

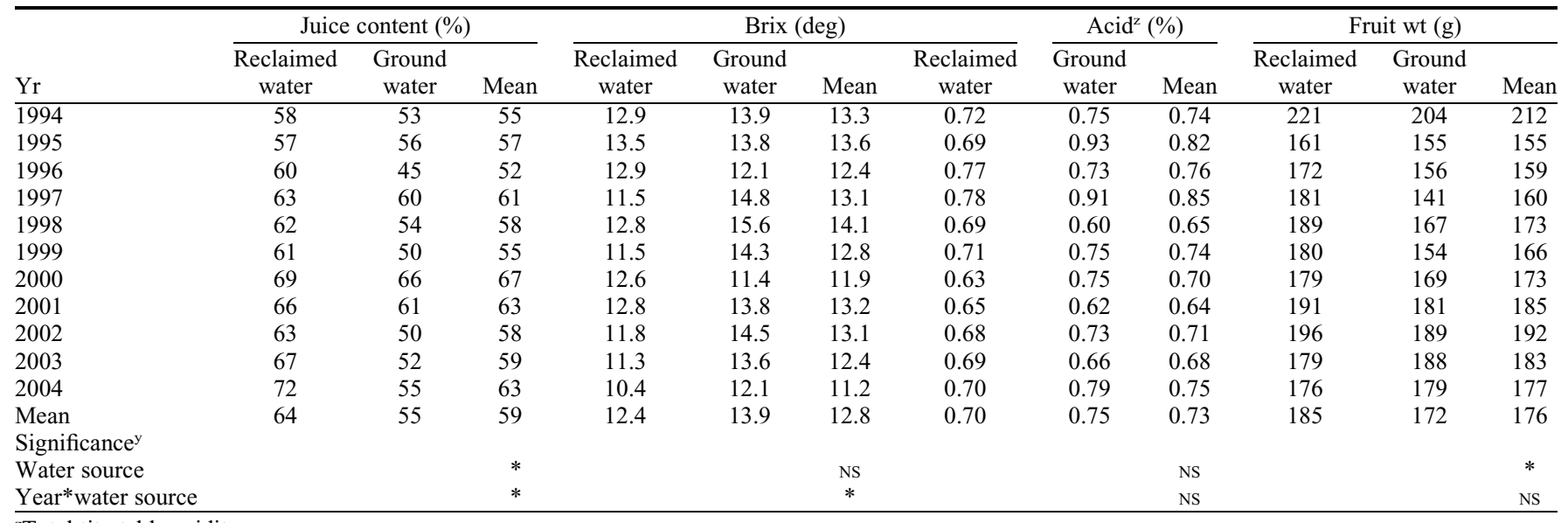

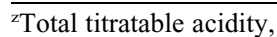

${ }^{\mathrm{N}} \mathrm{NS}$ and $*=$ nonsignificant or significant at $P=0.05$, respectively.

Table 4. Soil Mehlich 1 extractable elemental concentrations in samples taken in August or September of each year at three depths from orchards irrigated with reclaimed or groundwater between 1994 and 2004.

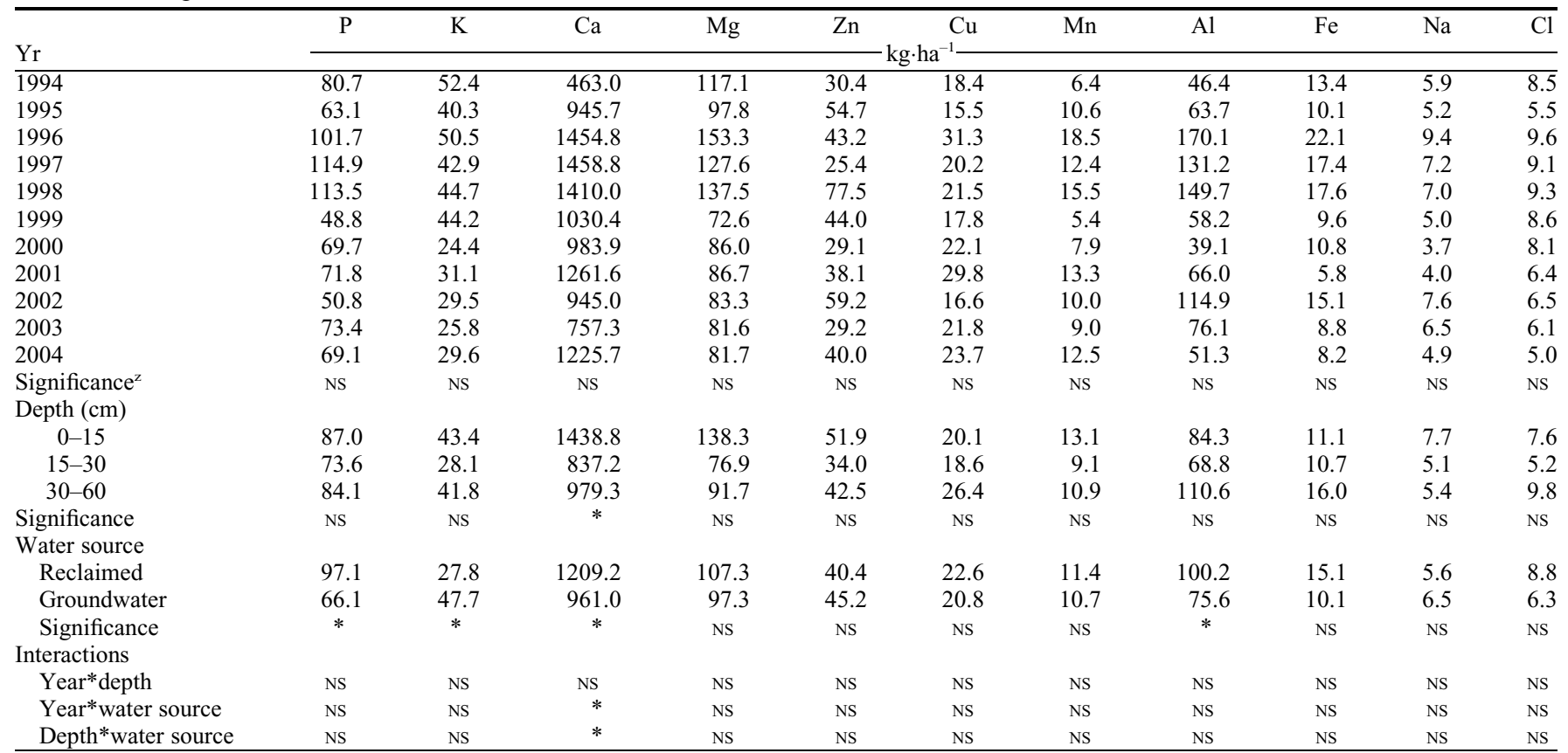

${ }^{\mathrm{z}} \mathrm{NS}$ and $*=$ nonsignificant or significant at $P=0.05$, respectively. 
Table 5. Mature spring growth leaf elemental concentrations in samples taken in August or September of each year from orchards irrigated with reclaimed or groundwater between 1994 and 2004.

\begin{tabular}{|c|c|c|c|c|c|c|c|c|c|c|}
\hline \multirow[b]{2}{*}{$\mathrm{Yr}$} & $\mathrm{N}$ & $\mathrm{P}$ & \multirow{2}{*}{$\begin{array}{l}\mathrm{K} \\
\%\end{array}$} & \multirow[t]{2}{*}{$\mathrm{Ca}$} & \multirow[t]{2}{*}{$\mathrm{Mg}$} & \multirow[t]{2}{*}{$\mathrm{Na}$} & \multirow[t]{2}{*}{$\mathrm{Zn}$} & \multirow{2}{*}{$\begin{array}{c}\mathrm{Mn} \\
\mathrm{mg} \cdot \mathrm{kg}^{-}\end{array}$} & \multirow[t]{2}{*}{ B } & \multirow[t]{2}{*}{$\mathrm{Fe}$} \\
\hline & & & & & & & & & & \\
\hline 1994 & 2.6 & 0.14 & 1.4 & 2.2 & 0.38 & 403.6 & 40.2 & 22.1 & 78.8 & 31.4 \\
\hline 1995 & 2.8 & 0.06 & 0.9 & 3.6 & 0.25 & 359.1 & 39.4 & 35.0 & 39.2 & 22.1 \\
\hline 1996 & 3.0 & 0.18 & 1.8 & 3.6 & 0.51 & 441.3 & 53.8 & 49.8 & 86.2 & 59.4 \\
\hline 1997 & 2.9 & 0.18 & 1.5 & 3.9 & 0.47 & 983.4 & 40.3 & 39.8 & 117.0 & 64.4 \\
\hline 1998 & 2.7 & 0.13 & 1.4 & 2.8 & 0.30 & 376.1 & 23.4 & 64.8 & 61.7 & 30.5 \\
\hline 1999 & 3.0 & 0.12 & 1.5 & 1.6 & 0.57 & 337.3 & 64.9 & 38.6 & 53.8 & 39.1 \\
\hline 2000 & 3.0 & 0.11 & 1.5 & 1.9 & 0.24 & 422.3 & 62.2 & 32.5 & 58.5 & 74.8 \\
\hline 2001 & 2.9 & 0.08 & 0.9 & 1.5 & 0.17 & 219.7 & 24.7 & 32.6 & 82.7 & 59.0 \\
\hline 2002 & 2.7 & 0.13 & 1.3 & 2.6 & 0.53 & 462.6 & 61.2 & 36.4 & 82.4 & 52.1 \\
\hline 2003 & 2.7 & 0.15 & 1.3 & 2.8 & 0.25 & 463.7 & 53.5 & 39.6 & 48.4 & 55.9 \\
\hline 2004 & 2.8 & 0.07 & 1.4 & 3.7 & 0.18 & 378.4 & 64.6 & 35.7 & 49.8 & 67.0 \\
\hline Significance $^{z}$ & NS & NS & NS & NS & NS & NS & NS & NS & NS & NS \\
\hline \multicolumn{11}{|l|}{ Water source } \\
\hline Reclaimed & 2.8 & 0.14 & 1.6 & 3.0 & 0.47 & 476.3 & 58.1 & 30.1 & 78.0 & 51.1 \\
\hline Groundwater & 2.8 & 0.10 & 1.1 & 2.5 & 0.24 & 405.1 & 37.9 & 47.5 & 59.9 & 49.9 \\
\hline Significance & NS & NS & NS & NS & * & NS & NS & NS & $*$ & NS \\
\hline \multicolumn{11}{|l|}{ Interaction } \\
\hline Year*water source & NS & NS & NS & NS & NS & NS & NS & NS & NS & NS \\
\hline
\end{tabular}

groundwater (data not shown). Likewise, soil calcium concentrations followed the same pattern with depth regardless of irrigation water source resulting in higher concentrations in soil irrigated with reclaimed water at the selected depths compared with soil from orchards irrigated with groundwater.

Like with soil samples, elements in mature spring flush leaves taken at the same time as the soil samples from orchards irrigated with either reclaimed or groundwater were not significantly different by year as indicated by the lack of year*water source interaction (Table 5). Leaf sample elemental concentrations were generally higher from orchards irrigated with reclaimed water compared with orchards irrigated with groundwater. Although higher, significantly higher phosphorus and calcium concentrations in soils irrigated with reclaimed water did not lead to significantly higher leaf concentrations. These results can be explained by dilution of leaf concentration by increased biomass production of trees irrigated with reclaimed water, reduced nutrient uptake efficiency, or a combination of the two. Unfortunately, differences in biomass accumulation were not determined in this study. However, only magnesium and boron were significantly higher in leaf samples from orchards irrigated with reclaimed water compared with samples from orchards irrigated with groundwater. Zekri and Koo (1993) found significantly higher iron and boron concentrations in more than half the years between 1987 and 1993. Based on this information, it is now recommended that orchards irrigated with reclaimed water not add boron to micronutrients sprays. Zekri and Koo (1993) found significantly higher sodium and chlorine concentrations in leaf samples from orchards irrigated with reclaimed water, presumably from higher irrigation applications. However, sodium and chlorine were not significantly different from 1994 to 2004, further indicating a change in irrigation practice among orchards irrigated with reclaimed water.

\section{Conclusion}

Few detrimental effects on citrus orchards have been associated with irrigation using the reclaimed water provided by Water Conserv II because the soils on which most citrus is grown in the Water Conserv II service area are very porous and drain rapidly. However, the impact of using reclaimed water on groundwater contamination were beyond the scope of this project. Appearance of trees irrigated with reclaimed water was usually better with higher canopy, leaf color, and fruit crop ratings than orchards irrigated with groundwater. These higher ratings are similar to results reported earlier. Higher weed growth in reclaimed water-irrigated orchards was associated with higher soil water content. However, growers apparently have made adequate adjustments to their herbicide practices. Higher soil water content in the orchards receiving reclaimed water resulted in reduced fruit soluble solids. However, because fruit crop ratings and larger fruit size indicated greater fruit yield, total soluble solids produced per hectare were similar to or higher in the reclaimed water irrigated orchards than in the groundwater-irrigated orchards. Like in the previous commercial orchard study, irrigation with reclaimed water increased soil phosphorus and calcium and reduced soil potassium. Reduction of phosphorus and calcium and increases in potassium applied to citrus orchards irrigated with reclaimed water may be required adjustments in fertilizer applications to citrus orchards irrigated with reclaimed water.

Likewise, leaf boron concentration was also increased, requiring an adjustment in foliar application practices. However, because nitrate- $\mathrm{N}$ concentration in the reclaimed water was less than $7 \mathrm{mg} / \mathrm{L}$, nitrogen uptake by citrus roots was probably limited and did not result in higher leaf nitrogen. Other work in the Vero Beach area in Florida showed that reclaimed water alone did not provide adequate nitrogen nutrition for young grapefruit trees (Maurer and
Davies, 1993), so current nitrogen fertilization practices will need to be continued. Therefore, long-term citrus irrigation with high-quality reclaimed water on well-drained sandy soils did not significantly reduce tree viability or yield and requires relatively little adjustment in production practices.

\section{Literature Cited}

Burton, T.M. and J.E. Hook. 1979. A mass balance study of application of municipal wastewater to forest in Michigan. J. Environ. Qual. 8:589596.

Campbell, W.F., R.W. Miller, J.H. Reynolds, and T.M. Schreeg. 1983. Alfalfa, sweet corn, and wheat responses to long-term application of municipal wastewater to cropland. J. Environ. Qual. 12:243-249.

Feigin, A., I. Vaisman, and H. Bielorai. 1984. Drip irrigation of cotton with treated municipal effluents. II. Nutrient availability in soil. J. Environ. Qual. 13:234-238.

Florida Department of Environmental Protection. 2005. Reuse inventory report. 28 Sept. 2006. $<$ www.dep.state.fl.us/water/reuse/inventory. $h t m>$.

Hanlon, E.A. and J.M. DeVore. 1989. IFAS extension soil testing laboratory chemical procedures and training manual. Inst. Food Agr. Sci., Univ. of Fla., Gainesville, Circ. 812.

Koo, R.C.J. 1963. Effects of frequency of irrigation on yield of orange and grapefruit. Proc. Fla. State Hort. Soc. 74:1-5.

Koo, R.C.J. and M. Zekri. 1989. Citrus irrigation with reclaimed municipal wastewater. Proc. Fla. State Hort. Soc. 102:51-56.

Marella, R.L. and M.P. Berndt. 2005. Water withdrawal and trends from the Floridan aquifer system in the southeastern United States, 1950-2000. USGS Circ. 1278. Washington, DC.

Maurer, M.A. and F.S. Davies. 1993. Microsprinkler irrigation of young 'Redblush' grapefruit trees using reclaimed water. HortScience 28:1157-1161.

McMahon, B.R.R., R.C.J. Koo, and H.W. Persons. 1989. Citrus irrigation with reclaimed wastewater. Trans. Citrus Engr. Conf. 35:1-17.

Neilsen, G.H., D.S. Stevenson, J.J. Fitzpatrick, and C.H. Brownlee. 1991. Soil and sweet cherry responses to irrigation with wastewater. Can. J. Soil Sci. Soc. 71:31-41. 
Obreza, T.A. and M.E. Collins. 2003. Common soils used for citrus production in Florida. Univ. of Fla., Gainesville, Bull. SS403.

Parsons, L.R. and T.A. Wheaton. 1992. Reclaimed water-A viable source of irrigation water for citrus. Proc. Plant Stress Tropical Environ. p. 25-26.

Parsons, L.R., K.T. Morgan, and T.A. Wheaton. 2001a. Wastewater and reclaimed water-Disposal problem or potential resource? Proc. Fla. State Hort. Soc. 114:97-100.

Parsons, L.R., T.A. Wheaton, and W.S. Castle. 2001b. High application rates of reclaimed water benefit citrus tree growth and fruit production. HortScience 36:1273-1277.
Perry, M.J. and P.J. Mackum. 2001. U.S. population changes and distributions 1990 to 2000. U.S. Census Bureau, U.S. Dept. of Commerce, Washington, DC. 28 Sept. 2006. <http:// www.census.gov/prod/2001 pubs/c2kbr01-2. pdf\#search $=\% 22$ Florida $\% 20$ population $\%$ $202000 \% 20$ growth $\% 22>$.

SAS. 1989. SAS/Stat user guide, Version 6. SAS Institute, Cary, NC.

Smith, S.K. 2005. Florida population growth: Past, present, and future. University of Florida, Bureau of Economic and Business Research Report. 28 Sept. 2006. <http://www.bebr.ufl. edu/Articles/FloridaPop2005.pdf\#search $=\% 22$ Florida\%20population\%201950\%22>.
Tucker, D.P.H., A.K. Alva, L.K. Jackson, and T.A. Wheaton. 1995. Nutrition of Florida citrus trees. Univ. of Florida. Coop. Ext. Serv. SP169.

U.S. Census Bureau. 1997. Florida population by counties. Dept. of Commerce, Washington, DC. 28 Sept. 2006. <http://www.census.gov/ population/cencounts/fl190090.txt $>$.

Wardowski, W., J. Whigham, W. Grierson, and J. Soule. 1995. Quality tests for Florida citrus. Univ. of Fla., Gainesville, Bull. SP 99.

Zekri, M. and R.C.J. Koo. 1993. A reclaimed water citrus irrigation project. Proc. Fla. State Hortic. Soc. 106:30-35. 